\title{
Importance, Fame, And Death
}

\section{GUY KAHANE}

\begin{abstract}
Some people want their lives to possess importance on a large scale. Some crave fame, or at least wide recognition. And some even desire glory that will only be realised after their death. Such desires are either ignored or disparaged by many philosophers. I argue, however, that although few of us have a real shot at importance and fame on any grand scale, these can be genuine personal goods when they meet certain further conditions. Importance that relates to positive impact and reflects our agency answers a distinctive existential concern for one's life, and existence, to matter. And since what is important merits wide appreciation, the step from wanting to be significant and wanting that significance fittingly and widely appreciated is small. Still, desires for importance and fame can take a more vicious character when they are not properly structured, and when they are not dominated by more impartial aims. If we accept the personal value of importance and fame, it is hard to see why that value cannot extend beyond our death; the temporal distribution of glory is actually irrelevant to its value. It is therefore a mistake to identify a concern with posthumous glory with the wish to leave a trace after our death.
\end{abstract}

\section{STENDHAL'S GAMBLE}

Henry Bayle died on the streets in Paris in 1842. The circumstances were ignoble: Bayle died of a seizure while the street children jeered, thinking he was just a drunkard. At the time, he was a relative unknown - none of his works was in print when he died. Bayle - more famous under one of his assumed names, Stendhal - described his audience as 'the happy few'. But he also predicted in 1830 that he will be 'understood about 1880 '. ${ }^{1}$ Elsewhere he wrote that he is 'putting a ticket in a lottery the grand prize of which consists in this: to be read in $1935^{\prime}{ }^{2}$ Stendhal obviously won a grander prize than he ever imagined. He remains widely read, and will be for a while.

The grand prize, I take it, was literary glory - or what some call literary immortality. ${ }^{3}$ Stendhal presumably didn't merely want to be read by someone, anyone, in the year 1935 , but to be widely known, to be considered a major, trailblazing literary figure. And if this is what Stendhal was hoping for, his hopes were fulfilled and more. Stendhal became, and remains, an important literary figure: his novels are classics, and Stendhal is seen as a key connecting link between Classicism and Romanticism. Not all important figures are famous, or even widely known. But Stendhal is a popular author, known to anyone with a passing knowledge of European literature, even if we cannot describe him as famous today in the sense in which a current celebrity is famous.

Stendhal's gamble succeeded, but I suspect that there will be those who find his ambition puzzling, even deeply irrational. For some, this will be because they think that seeking glory and recognition is itself foolish, a misguided goal. For others, what is puzzling is not the

\footnotetext{
${ }^{1}$ Stendhal first made this prediction in a letter to Balzac. See Gauss, C. (1923). 'Prophecies by Stendhal', Modern Language Notes, 38: 76-78.

${ }^{2}$ Cited in Smith, M. (1942). 'Stendhal, Hyphen-Mark in the History of French Fiction', The French Review, 16: 44-49.

${ }^{3}$ Canetti wrote of Stendhal that 'nowhere in modern times is a belief in literary immortality to be found in a clearer, purer and less pretentious form' (Canetti, E. (1962). Crowds and Power. NY: Viking Press). I take it as obvious that Stendhal's gamble was primarily self-focused - that he did not write simply out of concern for, say, the future state of French literature or out of some other purely moral or aesthetic aim; Stendhal was, after all, also the author of Memoirs of An Egotist.
} 
desire for glory, but for posthumous glory - for glory that you will never enjoy, that you will not even know about. It is good, they will think, that Stendhal's work was eventually recognised and widely enjoyed. But there's nothing in any of that for him, for Stendhal himself.

So some will find Stendhal's gamble puzzling. Others will find it perfectly intelligible. Now, few of us aim for glory of any kind, let alone posthumous literary glory. But this is because, for most of us, that is just preposterously out of reach. But many aim, or at least wish, for achievement and appreciation on a smaller scale. The wish to do, or at least link to, something of genuine importance, and to enjoy wide recognition, is common, even very common. ${ }^{4}$

There is something else that many people desire. Many people want their lives to be meaningful. But the desire for meaning is seen in a much more positive light than the desire for importance and fame. It is admirable to want your life to be meaningful, even if you ultimately fails. But wanting to be or do something important - to do it because it is important (as opposed to aiming to do something that also happens to be important) is, I think, treated much more ambivalently, even with suspicion. We certainly feel uncomfortable about those who act $a s$ if they are important - and even if this self-importance isn't entirely groundless. As for craving fame, this is widely seen as shallow, even embarrassing.

These rather different attitudes may help explain the rather different attention that meaning, importance, and fame have received from philosophers. At least more recently, there is much attention to the conditions under which a life might be said to be meaningful. ${ }^{5}$ There is far less written on importance (with some notable exceptions ${ }^{6}$ ) though this is also probably in part because it's not always properly distinguished from meaning (and some views come close to identifying the two). ${ }^{7}$ As for fame, there is nowadays very little philosophical interest in this topic, though there is of course a very long philosophical tradition of denigrating fame and those who crave it. The Epicureans, for example, recommended that we 'live unknown' (or unnoticed), ${ }^{8}$ and in Boethius's Consolations of Philosophy, Philosophy tells Boethius that fame is 'a shameful thing' ${ }^{9}$ A similar line is taken by Richard Kraut, one contemporary philosopher who does discuss fame. He describes fame as one of the 'vanities', those things that are widely desired despite being worthless in themselves; one of the aims of philosophical reflection on the good is precisely to release us from the grip of such vanities. ${ }^{10}$

Importance and fame would deserve philosophical attention simply in virtue of being commonly desired, even if they lacked genuine value. But I will argue that once we get clearer about what importance and fame are, and how they are related, a case can be made that they both possess final value - final value for the person who possesses them - at least

\footnotetext{
${ }^{4}$ Samuel Johnson went so far as to assert that '[e]very man, however hopeless his pretensions may appear, has some project by which he hopes to rise to reputation; some art by which he imagines that the attention of the world will be attracted; some quality, good or bad, which discriminates him from the common herd of mortals, and by which others may be persuaded to love, or compelled to fear him'. (The Rambler, 1751).

${ }^{5}$ See e.g. Wolf, S. (2012). Meaning in Life and Why It Matters, Princeton University Press; Metz, T. (2013). Meaning in Life, Oxford University Press.

${ }^{6}$ See e.g. Frankfurt, H. (1999). 'The Usefulness of Finals Ends' in his Necessity, Volition, and Love (Cambridge University Press); Nozick, R. (1989). 'Importance' in The Examined Life, Simon \& Schuster. For an insightful discussion of glory, see Chappell, T. (2011). 'Glory as an Ethical Idea'. Philosophical Investigations, 34: 105-134.

${ }^{7}$ For discussion, see Kahane, G. (forthcoming), 'Meaningfulness and Importance' in Landau, I., ed., The Oxford Handbook of Meaning in Life, Oxford: Oxford University Press.

${ }^{8}$ Roskam, G. (2007) Live Unnoticed: On the Vissicitudes of an Epicurean Doctrine. Brill. Plutarch criticised this doctrine in in Plutarch (1967). Moralia, XIV. Cambridge, MA: Loeb Classical Library.

${ }^{9}$ Boethius (1969). The Consolation Of Philosophy, trans. V.E. Watts. London: Penguin Books.

${ }^{10}$ Kraut, R. (2007). What is Good and Why. Cambridge: Harvard University Press.
} 
when they meet certain conditions. We should distinguish this question about the value of importance and fame from the further question of how we should evaluate desires that aim at them: even if importance and fame are worth having, it won't immediately follow that wanting them is worthy. Whether such desires are appropriate or vicious depends, I will argue, on how they relate to each other and to other, more selfless aims.

I will end by returning to Stendhal, and the desire for posthumous glory. To write a book takes time, and effort. There are other ways Stendhal could have spent his time, other projects he could have pursued. Even if he sought literary success, he could have tried to write in a style his contemporaries were more likely to appreciate. The desire for so-called literary immortality is often interpreted as reflecting the wish to somehow overcome death. But whether leaving a trace in this way is worthwhile or utterly pointless, it is distinct, I will argue, from both importance and fame (though the three can interact or overlap). The desire for posthumous glory is perfectly sensible not (or not only) because it is a way to transcend death, but because the value of glory - the value of importance and fame - is simply independent of one's life and its limits. It is a value - a value for oneself - that can transcend death, but whether or not it transcends death is simply irrelevant to its value. ${ }^{11}$

\section{IMPORTANCE}

We can start with importance. What does it take for something to be important (or significant, consequential, noteworthy, seminal, key, and so forth)? I will draw here on an account of importance that I've developed in more detail in other work. ${ }^{12}$ I call it the value impact view of importance. It starts from the thought that to be important is to make a difference. Now, there are all sort of differences one can make, and many of these would be trivial. But the kind of difference that's genuinely important - the kind of difference that's worth making - is, perhaps unsurprisingly, a difference to what matters, that is to say, to what has final value. So importance is a function of final value, yet something's importance isn't the same as how much final value it has, or even how much final value it brings about. To begin with, unlike final value, a thing's important is relative to a domain or context. Quine is an important philosopher but he's not an important political figure or even especially important in the context of, say, late $20^{\text {th }}$ US history. In many cases, the relevant domain will be at least partly defined in spatiotemporal terms, though this needn't be so.

Another way in which importance operates differently from final value is that it is relational: it involves a comparison (implicit or explicit) with what else is in the domain with other difference-makers. This is another reason why how important one is depends not on how much final value one brings about absolutely, but how much final value one brings about compared to other things: a disfiguring skin condition might be a pretty important thing in a person's life, but its importance would instantly shrink against the background of a catastrophic plague. Similarly, a simple doodle that would be of no significance whatsoever if inscribed on a cave wall today may be of momentous importance if it is the work of a Neolithic craftsman.

${ }^{11}$ I will be speaking about the personal value of glory, including posthumous glory, but I don't think it's useful to see it as adding some further quantity to a person's pile of 'well-being'. So I don't want to say that by reading Stendhal today, we are literally benefiting him or that Max Brod would have gravely harmed the recently deceased Kafka if he had destroyed his written work as requested. But I still want to say that there was something in it - in later glory - for them, for Stendhal and Kafka themselves, not just for their readers. For a similar distinction between well-being and meaning, see Metz, Meaning in Life.

${ }^{12}$ See Kahane, G. (2014). 'Our Cosmic Insignificance', Noûs, 48, 4: 745-772 and in particular (2021). 'Importance, Value, and Causal Impact', The Journal of Moral Philosophy, where I also discuss purely 'descriptive' senses of importance that aren't linked to value in this way. 
I have offered a sketch of what makes something more, or less, important. We can next ask what follows from importance - ask about its normative upshot. Put simply, to be important is to merit being treated as important. And to be treated as important, I say, is to receive proportional attention, and to be given sufficient weight - though the specifics can vary depending on the domain and the kind of value involved. Put differently, we can say that to be important is to matter objectively, and to be treated as important is to matter subjectively, to matter to others. And things go well, normatively speaking, when the two align.

So people, things, events and acts can be more or less important by making more or less of a difference to the overall value of some domain, and in virtue of that merit more or less of the attention of those concerned with that domain. Some people are resistant to the idea that some people are more important than others. They want to insist that all people are equally morally important. ${ }^{13}$ But by this they just mean the idea that all of us have equal moral value, and equal moral status. This, however, is a different notion of importance, roughly relating to the moral weight that each of us should get in moral deliberation. ${ }^{14}$ But it remains the case that, say, Confucius, Napoleon, Queen Victoria, Adolf Hitler, and Nelson Mandela are figures of immense importance on the largest scale, while you and I are not. And as some of these examples bring out, the impact that makes someone or something important may be incredibly negative. ${ }^{15}$ Importance in this sense just is not a moral notion.

\section{FAME}

Fame is primarily used as a categorical term in the sense that you are either famous or you're not. But we can also say of someone that they are more famous than another. So to be famous in the categorical sense is to be famous enough in the degree sense. It is this degree sense that interests me, even when it applies to cases we won't describe as famous, categorically speaking.

I don't think we have a good label for this much broader property, so I'll still use 'fame' (in the degree sense) to describe it. This property is, in the first instance, a cognitive one - it relates, roughly, to how much someone or something is known. As with importance, there is relativity at work, whether implicitly or explicitly, since we can have in mind different populations of potential knowers. Someone can be famous in France but obscure in the US, famous in cancer research but obscure to the general public, a global sensation this week but forgotten in a month's time, etc.

The relevant cognitive property is complex and involves multiple dimensions. ${ }^{16}$ Focusing on the case of persons, there is, for example, how many people know about someone, to what extent they know who that person is, how much they know about them and what they did, and the degree to which this knowledge is dormant (simply something they could recall, if the occasion arose) or regularly salient (something that's often on their minds). These

\footnotetext{
${ }^{13}$ Nagel speaks of the sense in which, from an objective standpoint, 'no one is more important than anyone else' (Nagel, T. (1986). The View From Nowhere. OUP, 171).

${ }^{14}$ As this example shows, there is a further normative sense of importance not covered by the value impact account - the difference something should make in the context of deliberation.

15 The example of Napoleon raises a worry. Napoleon was obviously of great historical importance but can we confidently say that his impact was overall positive or negative? One way to go is to point out that Napoleon's life made a great difference to what things had value (both positive and negative) even if it, say, turns out that his positive and negative impacts largely cancel out. But I'm not sure this solves the problem.

${ }^{16}$ In thinking about fame, I have benefited from Halberstam, J. (1984). 'Fame'. American Philosophical Quarterly 21:93-99; and Lackey, D (1986). 'Fame as a Value Concept'. Philosophy Research Archives 12: 541551.
} 
variables can come apart in numerous ways - most of us know Stendhal via his assumed name, and far fewer would recognise his real name; Homer and Shakespeare are among the most famous of literary figures, yet we know nearly nothing about the first, and rather little about the second, etc. But I won't offer an account of the weight that these different factors have in determining the degree of someone's fame.

But while fame is primarily a cognitive property, very often - and in the sense that people typically desire - fame involves more than bare cognition. There is also an affective, evaluative aspect. This is brought out when, for example, we describe people who are famous for unpleasant things as infamous - and clearly that implies a degree of contempt, a negative attitude. Conversely, celebrities are those that are, in one sense, celebrated. People closely follow celebrities because, in at least some minimal sense, they care about them and what happens to them; they do not report the latest scandal in a matter of fact tone. Conversely, if someone's name and key facts of their lives are used in a textbook grammar exercise used by millions of schoolchildren, who recite these facts in monotone, not even as the butt of some recuring joke, then this person enjoys fame only in an attenuated sense even if they possess the purely cognitive property to a considerable degree.

\section{IMPORTANCE AND FAME}

At this point the relation between importance and fame should be obvious. Roughly, fame is what importance merits. The famous receive a great degree of attention and concern. Whether or not they are important, the famous are treated as if they are important. Now one of the very oldest complaints is the complaint that the two rarely align, that what is truly important is ignored or overlooked, that people pay most attention to the trivial, and celebrate the superficial, frivolous, and shallow. Famously, some people are 'famous for being famous'. ${ }^{17}$ Though we shouldn't exaggerate. What's really important and what's actually famous (in the broad sense) aren't completely unrelated. Very many truly important things receive a great deal of attention - a global epidemic, a war, a recession.

Moreover, even when the two do align, it's not correct to say that fame is simply what rightly follows (recognised) importance. The relation is more complex: often people and things acquire importance by being famous, and their importance is sustained by their fame. The more widely Stendhal was read, and appreciated, the greater was his influence, and his importance grew. And his influence over time largely depended on him being continually read, discussed, etc., and in this way, having further impact. While it's possible to have great impact in complete obscurity, even, in some cases, with the difference you made being completely unknown, this is fairly rare. Napoleon wouldn't have achieved the impact he had in his own life without being known by numerous people, indeed, without being incredibly famous. And a great deal of his posthumous impact was mediated by this continuing fame.

Return, finally, to the idea of being famous for being famous. The idea here is of someone who is famous despite clearly not meriting such fame - despite being unimportant. But to begin with, you obviously cannot first become famous because you are famous. You become famous in some other way, and because of that initial fame you become even more famous. Conversely, although you may be famous, to begin with, without meriting any such

${ }^{17}$ Martin Amis's short story 'Career Change' dramatizes this by portraying a counterfactual world where Hollywood actors recite poetry to great crowds, and poets are feted and receive vast salaries for their latest sonnet, while sci fi screenwriters languish, publishing their scripts in obscure underground magazines. But Amis's aim is presumably ironic: one point of the story is that poetry would be degraded if it were linked to fame in this way and turned to a mass market product and vehicle for star vanity projects. But this is compatible with thinking that this counterfactual world is superior to ours. See Amis, M. (1998). 'Career Move', in his Heavy Water and Other Stories. London: Jonathan Cape. 
attention, fame, as we have just seen, can generate importance of a sort. The celebrity influences millions on a daily basis, affecting their mood, and bank accounts. So there is bootstrapping here: by being famous, one acquires a degree of importance, and thereby begins to actually merit a degree of fame. (Although, all the same, the importance one acquires in this way is relatively modest and won't justify receiving that degree of attention over many other, more important things.)

\section{THE VALUE OF IMPORTANCE}

So I've said something about what importance and fame are, and about their relation. I now turn to ask whether they are at all worth having.

Let's start with importance. No doubt, in many contexts, greater importance has its instrumental benefits, though these are rarely directly brought about by importance itself they are typically the social upshots of perceived importance (and in some cases, even of fame). Still, I take it as plain that at least some people desire importance non-instrumentally, even in the absence of such reward. They desire, for example, to find a cure for cancer or vaccine that protects against COVID-19 and desire to do so, at least in part, because by doing so they will have done something important, something noteworthy.

An obvious way to show that importance is desired for its own sake are cases of desire for posthumous importance - think again of Stendhal. He did become an important figure in French literature, an influence on Nietzsche, etc. But those posthumous events could not make Stendhal happier or help him with his debts.

Now some people may want importance because they see it as a path to fame (even to posthumous fame). We cannot rule out this was the case with Stendhal. So for such people importance is still instrumental, and whether it has value will depend on whether fame has value - something we'll turn to below. But at least some people value importance even in the knowledge that no one will ever know about it. Think of a cold war mole of whom nothing is known even by her handlers. ${ }^{18}$ The mole would probably (though not necessarily) prefer to be known and celebrated at some point. But this is not a condition for the value, for them, of their critical historical role. And in some cases, people may actively seek to avoid fame. Think of anonymous philanthropists.

Now the cold war mole, the anonymous philanthropist, may have powerful impartial, or at least not self-centred reasons to do what they do. They want the good side to win, to save many lives, etc. And no doubt in such cases, these reasons are also overwhelmingly sufficient for doing what they do. But I submit that, in at least some such cases, these people don't merely want that independently valued, more impartial outcome to be realised. They also want to be the ones realising it, or at least playing a big role in doing so. There's an agentrelative, self-centred element here, something rewarding to them - they don't just want to make that impartial difference to value, which will also happen to endow their act with importance; they also want to do something that is important. In at least some cases, people may even start out desiring the latter, abstract property, and look for feasible first-order ways of realising it. ${ }^{19}$

So I claim that at least some people desire importance for its own sake, and desire it for their own sake. ${ }^{20}$ It doesn't follow that importance of any kind is desirable. Think of a lab

\footnotetext{
${ }^{18}$ For a similar example see Benatar, D. (2017). The Human Predicament (Oxford University Press).

${ }^{19}$ Effective altruists tell us to ask ourselves: 'how I can do the most good?'. But we can put the emphasis both on 'most good' and on 'I'.

${ }^{20}$ Some will no doubt respond that it's the instrumental benefits of importance (or fame) that lead people to care about them but that some people confusedly come to desire them for their own sake. I don't have space
} 
technician whose lazy negligence launches a deadly global epidemic. This would be an incredibly important event. If it spells the end of humanity, the negligent technician would arguably be one of the most important people who had ever lived. But this kind of importance doesn't seem worth having. There are two things are work in this example: whether the difference one makes is positive or negative, and whether that difference reflects one's directed agency. With respect to the first, I think that it is attractive to hold that it is worth making a difference, for one's own sake, only if that difference is positive; it needs to be impartially good to be also personally good. But it's hard to deny that at least some people seem to seek importance, and even make great personal sacrifice to do so, even though they are well aware that the difference that they make is purely negative (think of those who try to become important by assassinating a political leader or cultural figure - who hope to achieve something important by killing someone who is already important). I suspect that these people are making a mistake in thinking that there's anything for them in such acts. But an alternative view would be that making such an impact is a person good even if the moral reasons against acting in this way are overwhelmingly decisive. The line we take on this question will presumably depend on the line we take about parallel questions about, for example, the personal value of taking pleasure in others' suffering, or of so-called 'antimeaning'. ${ }^{21}$

Even those who think there's value in importance of any kind would presumably still accept the further condition that this impact should be properly traced to one's directed agency, and perhaps also be consonant with one's attitudes. But again I suspect that at least some would hold that there's at least something for us in, say, being the person with the rare genetic mutation whose discovery made it possible to eradicate a serious disease. ${ }^{22}$

I've so far tried to show that at least some people value importance for its own sake, and explored some conditions importance might to need meet to be a candidate for value. This leaves it open why importance has that value, even when it meets these conditions. Here is a sketch of an account. The basic idea is this. I think that importance can address a distinctive existential concern: the wish for one's existence to matter. When people worry that they, or their lives, are utterly insignificant, they worry, I believe, that what they do, that even their very existence, makes little or no difference to the world around them. As Nagel puts it, '[1] ooking at [one's life] from the outside, it wouldn't matter if you had never existed'. ${ }^{23}$ Importantly, your existence might not matter, in this broader way, even if you are happy, if your life possesses considerable value, even if your life is deeply meaningful.

To see the how meaningfulness and important can come apart, think of Bill and Hilary Clinton. The Clintons remain important political figures. But since he left the White House, Bill Clinton is not remotely important as he was as when he was president. And Hilary Clinton is not remotely as important as she would have been had she won the 2016 US elections. Perhaps, in a range of respects, their lives are more meaningful compared to that

to assess such a debunking strategy but for my purposes here it's enough to point out that it is just as easy to mount such an attack on altruist or non-hedonic aims.

${ }^{21}$ See Campbell, S., \& Nyholm, S. (2015). 'Anti-meaning and why it matters.' Journal of the American Philosophical Association, 1: 694-711.

${ }^{22}$ To the extent that one accepts that importance has value only when it involves positive difference and one's directed agency, then one comes close to holding that importance has value only when it meets criteria that some see as grounding meaningfulness (see especially Metz, 2013). But while I think there may be a case to be made that importance has final value only when it is also meaningful, I don't think the value of importance is merely that of meaning (unless, of course, we prefer to think of desirable importance as a distinct kind of meaning; but I don't find such an expansive terminology helpful). For further discussion of the relation of importance and meaning, see Kahane, 'Meaningfulness and Importance'.

${ }^{23}$ Nagel, T. (1987). What Does It All Mean? (Oxford University Press). 
prior or counterfactual life. But we'll easily understand if they nevertheless feel a sense of loss, even deep loss.

Several authors link meaningfulness to certain fitting attitudes, including third person attitudes such as admiration. ${ }^{24}$ Think of someone who lives a life of quiet decency, bravely facing adversity and, despite many obstacles, rearing a flourishing family. When we meet such a person, or reflect on such a life, we should respond with admiration. Yet it's not true that there is a reason for everyone to know about and admire that life, or that their name should be emblazoned on the front pages. Meaningfulness doesn't, on its own, call for general attention - it isn't especially noteworthy. It's important for the person, but It isn't important in the everyday sense we are talking about. If that life is removed from the world something valuable and meaningful is removed but the world is nevertheless not substantially different overall. ${ }^{25}$ In other words, because it doesn't make a significant overall difference to value, such a life doesn't objectively matter such that one should subjectively matter to (relevant) impartial observers.

\section{THE VALUE OF FAME}

The value of fame is harder to defend - if anything, it is widely seen as a paradigm of something that is desired despite having no inherent value. Why should it matter whether one is known (even favourably known) by numerous strangers? This is compatible with valuing fame instrumentally, for its typical causal benefits. Yet it again seems clear that some people desire fame independently of such benefits and even when they don't expect them. If anything, people make considerable sacrifices, even absurd sacrifices, to get even a longshot at a moment in the limelight. And again there are those cases, even if uncommon, of people who make considerable sacrifices - sometimes even risking their lives - in the hope of obtaining posthumous fame. ${ }^{26}$ Such acts are clearly done without instrumental intent or expectation.

If fame and importance aligned often enough, then fame might have epistemic value offering collective support to one's own perhaps shaky judgments about the impartial value of what one has achieved, and thereby also externally validating its importance; contrast the epistemic loneliness of the misunderstood artist. But such epistemic significance would only be a way to track the prior personal value of importance, and won't add further personal value, nor would such a role justify a concern with posthumous fame. And of course in many cases the relation between importance and actual fame is flimsy at best.

Another way in which the value of fame may derive from that of importance we already saw: I said earlier that fame often plays a role in amplifying and sustaining importance, especially posthumous importance. If importance has personal value, then fame that promotes one's impact can acquire critical instrumental value.

We are asking, though, whether fame itself might have final value. There is actually a straightforward way to argue that fame has impartial value when it is merited and proportional. I have in mind here the view that it is good to love the good, and to hate the

${ }^{24}$ See Kauppinen, A. (2012). 'Meaningfulness and Time'. Philosophy and Phenomenological Research, 84: 345-377.; Metz, Meaning in Life.

${ }^{25}$ Though this needs to be qualified in two ways. First, our imagined removal can still make a difference (remove something of importance) on much smaller scales and, for some, that would be enough. Second, while our individual removal may not make a real difference this needn't be true of our collective removal. For discussion of our potential collective significance on the largest, cosmic scale, see Kahane, 'Our Cosmic Insignificance', and 'Importance, Value, and Causal Impact'.

${ }^{26}$ Perhaps the most famous example is Herostratus who burned down the temple of Artemis at Ephesus in order to be remembered by posterity. 
bad. ${ }^{27}$ To the extent that fame is accompanied by fitting attitudes ${ }^{28}$ then on such a view fame (as well as infamy!) arguably has final value - the world is better when acts and events of importance are fittingly appreciated. I say arguably since the view that it's good to love the good typically focuses on fitting appreciation of final value and importance often supervenes on instrumental value - the importance of a declaration of war derives not from the value it directly realises (e.g. the moral cowardice or courage it reflects) but from its wide further effects - all those lives or freedoms saved or lost. It is less clear that we add final value to the world simply by appreciating the things that brings about final value as opposed to appreciating that final value itself. Notice also that if we accept that such responses themselves possess impartial value, then we must also accept a kind of feedback loop: fame is not only a conduit for further importance, through the value impact it enables, but is itself directly a value impact, and thereby directly amplifies a thing's importance, meaning that such fame calls for yet further fame, which then calls for yet more, and so on.

If this is right - and I don't pretend to have shown that it is - then we have impartial reasons to promote merited fame (and infamy) - say, to rediscover an overlooked singersongwriter or inventor or make more widely known a forgotten atrocity, and uncover its perpetrators - even if this won't help any of its long death victims. Still, this doesn't show there's anything in that for that now fashionable singer-songwriter.

But it seems to me that if importance has personal value, and if it calls for a certain kind of response, then it is a small step to thinking that it is a further personal good if that importance is acknowledged and fittingly appreciated (or we can say instead that the personal value of importance is more fully realised when it is thus appreciated).

Even if we accept this further step - that it's good for us not just to be such that we merit a certain response, but also that we in fact receive that response - there is still a gap from ascribing any final value to fame. This depends on how we understand the relevant merited response. To begin with, responses can come in different forms, ranging from superficial approval to close, deep engagement. Nor is it obvious that the numbers should count. Thus, why isn't it enough if a handful of people appreciate the importance, appreciate it deeply and from up close, as opposed to the offhand knowledge of millions? ${ }^{29}$ It might be thought, in particular, that it's not the fickle opinion of the masses that should matter but that of a few close intimates (or perhaps, even, just of oneself). ${ }^{30}$

We needn't deny that degree of evaluation, and its depth, matters. But that such responses count for more is compatible with thinking that the numbers matter. That, for example, an exquisite response from a wide, highly educated musical audience is better than such a response from a single listener. ${ }^{31}$ And while often the nearby has deeper, more sustained response, this isn't always the case. Distant future critics may devote an entire life

${ }^{27}$ See especially Hurka, T. (2000). Virtue, Vice and Value. Oxford: Oxford University Press.

${ }^{28}$ In other work, I've suggested that when we attend to value from a great temporal distance, fittingly responding to it may require not much more than cognitive response, so long as that response is governed by one's recognition of the thing's value. See Kahane (2021). 'The Significance of the Past', The Journal of the American Philosophical Association.

${ }^{29}$ Responding angrily to a very favourable journalistic piece on his work, Degas remarked that 'one works for two or three living friends, and for others one has never met or who are dead' (quoted in Mulhlstein, A. (2016). 'Degas Invents a New World', The New York Review, May 12).

${ }^{30}$ Valery thought that Stendhal was "divided between his immense desire to please and to become famous, and the opposite mania, his delight in being himself, in his own eyes, in his own way. He felt, deeply embedded in his flesh, the spur of literary vanity; but he also felt a little deeper down the strange sharp pricking of an absolute pride determined to depend on nothing but itself." (Valéry, P. (1989) 'Stendhal', trans. M. Turnell, in Bloom, H. ed. Stendhal, NY, Chelsea House, 7-30.)

${ }^{31}$ I set aside, though, the question of how to weigh few deep responses against many more shallower ones. 
to studying Stendhal's work, they may see things that contemporaries (let alone close friends) cannot. Things that even Stendhal himself could not see.

\section{WORTHY MOTIVATION}

Even if importance and merited fame possess final value, it doesn't follow it is always admirable to aim to have these things. Concern for one's importance, and even more so for fame, is seen as embarrassingly egocentric, even narcissistic. It is no doubt self-focused, but in this respect it is no different from the desire for happiness or even meaning in one's life. We don't desire merely that there be more happiness out there. We may desire that, but we also desire our own happiness. And while people often enough aim to do certain things selflessly - things such as helping others - that also endow their lives with meaning, often enough they also directly seek meaning. And here they don't just seek there to be more meaning out there. They want their life to be meaningful. Wanting to be linked to something important, to do something important and even, in virtue of that, to oneself possess a degree of importance aren't different. Now importance does have an inherent relational, comparative dimension that happiness and meaningfulness do not. But this doesn't mean that aiming at importance is essentially competitive. You can want to stand out without wanting others to stand out less.

The desire for others' attention, for everyone's eyes to be one you, can again seem harder to defend. However, we are not talking about wanting others' positive attention regardless of whether that is merited, or even when it's actually undeserved. When something important happens, others already have reason to attend to it. The claim is just that there is an agentrelative reason to want some others to respond to that independent impartial reason.

Our evaluation of the desire for personal importance and fame is complicated by the obvious point that the vast majority of people have little or no shot at importance or fame on a large scale. It is straightforwardly irrational to devote considerable efforts to a goal that is out of reach. Even mere longing for such things will typically be demoralizing or worse, and such fantasies are therefore best kept out of mind by most of us. And because glory is out of reach for most of us, there may be a reluctance to admit its value and to respect its pursuit by those who do have a shot; Nietzschean ressentiment may be at work.

This is not to deny that the pursuit of such things, especially when it is all consuming, isn't often associated with attitudes and dispositions that are deeply unpleasant; the narcissist may obsessively seek others' admiring attention as a way of dulling his underlying sense of insignificance. ${ }^{32}$ Even setting aside such psychological associations, desiring glory can be problematic if the relevant desires are not structured properly. ${ }^{33}$

In the Analects, the Master is recorded as saying 'A man should say... I am not concerned that I am not known, I seek to be worthy to be known. ${ }^{34}$ In one way, Confucius

\footnotetext{
${ }^{32}$ In his short story 'Good Old Neon', one of David Foster Wallace's characters described what he calls the 'fraudulence paradox': the more he succeeds in impressing others - in winning their admiring attention - the less he impresses himself, and the more empty he feels inside - a spiral of self-loathing that ends in suicide. The story doesn't make clear whether this character thinks that the admiring attention is deserved. It would not be surprising if immense skills in manipulating others into admiring you despite not being worthy of such admiration is ultimately unsatisfying. But it is hard to consistently impress others without offering them something that is genuinely impressive, at least to a degree. Why then loath oneself for receiving merited appreciation? The problem, I think, is that the focus remains on others' attitudes, with what merits these attitude serving merely as a means. So even when there is genuine value being produced, it is not only playing a derivative role but, for that reason, also arguably being devalued. Foster, D. W. (2004) 'Good Old Neon' in his Oblivion: Stories. Little, Brown, and Co.

${ }^{33}$ For a different account of the motivation for glory, see Chappell, 'Glory as an Ethical Ideal'.

${ }^{34}$ Confucius (1861). The Analects of Confucius (Legge, J. Trans.). Oxford: Clarendon Press. IV.14.
} 
doesn't go far enough here. We should be concerned, it might be argued, about doing the things we ought to do and doing them well; we should aim to bring about what has value simply because it has value. Nor even because it merits an appreciating response. On the other hand, while a completely selfless attitude might be especially admirable, once we allow self-centred attitudes into the picture - again, desiring one's own happiness or having a meaningful life being examples - it's hard to see why we can't also be concerned, for our own sake, with the importance of what we do, and with that importance receiving wide fitting appreciation. These more selfless and self-centred attitudes are perfectly compatible. It's just a question of how they are ordered in our motivational set.

Take the cliched example of finding a cure for cancer. For a scientist who has a shot at finding such a cure, the primary aim should be the impartial one of finding such a cure because of its extraordinary moral value - the untold suffering it will prevent. But it seems perfectly acceptable to also wish, more weakly, that this cure be found by oneself, or one's team; that you will be the one to realise that impartial value (what is vicious is not to want that, but to want that either you find the cure, or no one will). You may further (even more weakly) prefer that one's contribution to that impartial goal stands out in some way - that you make some distinctive, decisive contribution as opposed to moving things slightly forward alongside a small army of other researchers. You may next prefer that, if you make such a contribution, it will be widely and fittingly appreciated, as well as (even more weakly) that it be appreciated as your contribution (again what is vicious isn't that but wanting to make a contribution only in order to be widely appreciated, or even to be widely appreciated for no good reason, or even on fraudulent grounds). You may also, moreover, wish to be in a position to know that you did something important, and that this was fittingly appreciated. In this way you must, at each point, priority to the more fundamental motivation.

The question of motivation may also be affected by the kind of value in question. It is easiest to see such motivations in approving terms in the aesthetic case. After all, a fitting response is likely required to even generate aesthetic value. And even if we hold that works of art have value even if not appreciated by anyone, few would deny that far more aesthetic value is realised once we add the fitting aesthetic response. Accordingly, it would seem odd for an artist not to be at all concerned whether anyone comes to appreciate their work, and positively perverse for them to prefer no one to so appreciate it, or even for it to be misunderstood or ridiculed. When we turn to achievement, including intellectual achievement, the value in question is more plausibly seen as independent of further appreciation. But it doesn't seem especially problematic to desire to be the one making that achievement and even for it to be fittingly appreciated as one's own. The trickiest case is probably the moral domain. It is common to see any element of self-regard as undermining moral praise. To the extent that moral acts merely aim at such praise, such undermining would certainly follow. Still, when the different motivations - impartial and self-concerned are properly ordered, it's not obvious that the mere presence of the latter must besmirch the former.

\section{DEATH}

We can finally turn to the question of the relation between importance, fame, and death. Suppose we accept that importance is a final personal good, as is deserved fame, in the sense of wide positive recognition of positive importance (to simply things, I will continue to speak of importance and fame, simply assuming these qualifications). To the extent that we accept this, the idea of the value of posthumous importance and fame seems perfectly straightforward. How important or famous someone needn't have anything to do with how long they live or whether they are even alive. And to the extent that these things possess 
value, it's hard to see why that value should be cancelled when the person dies. If so, this is a personal good that can extend beyond our death (and in some cases, such as Stendhal's, even largely begin after our death). In that way, it's a personal good that can transcend the limits of human life. Yet, at the same time, its final value is in no way derived from or even amplified by this death-defying feature. How important or famous you are, and whether or not you are alive, are simply independent.

If importance and fame are independent of one's life, can they also extend before one's birth or conception? The idea of pre-conception fame seems straightforward. Think, for example, of a long-anticipated messiah, the object of longing for centuries before his arrival. That anticipation may utterly shape the course of history, though it's less obvious that we want to say that messiah's importance extends before his actual appearance (as opposed to the importance of people's anticipation).

In fact, so far as I can see the temporal (and spatial) distribution of one's impact, or fame, is simply unimportant. ${ }^{35}$ What matters is what comparative difference to value you make to a domain, not where or when you make it - whether during life or after your death, over a minute or over centuries. In practice, of course, one can typically have more of an impact if one's causal effect on value extends further in space and time. But that is just contingent. The same for fitting appreciation: most of the potential 'audience' for what people do probably lies in the future and, of course, we cannot reach a past audience. But these are contingent matters. Imagine a spiritual leader who emerges in humanity's last decade, helping guide it to final enlightenment before it peacefully bows out. Such a leader would be both maximally important and famous. Yet that importance and fame may be concentrated over a relatively brief period of time, perhaps just a few years.

This is a point about the spatiotemporal spread, and the distribution, of one's importance and fame. ${ }^{36}$ What matters, I suggested, isn't where that importance and fame is located, spatiotemporally, but how much difference to overall value one makes, and how many people appreciate that difference and to what degree. That difference to value, for example, may be highly concentrated spatiotemporally, as in the spiritual leader example above. At the same time, if we say that this leader was an extraordinarily important figure in the history of humanity as a whole, then this leader just is important on that grand scale, even though her causal impact is incredibly narrow in reach. ${ }^{37}$

People sometimes desire to leave a mark; we could interpret Stendhal's gamble in such terms. But to describe someone as aiming to leave a mark is ambiguous. To leave a mark can refer to doing something important on a grand enough scale. But it can also refer to leaving a lasting trace. ${ }^{38}$ These are different things. To begin with, one can leave a trace that goes on for a long time but isn't important. Think of being remembered within one's family for many generations. Or even the forward impact people believe they can have via having a long line of descendants. Neither need count as important in any interesting sense. Conversely, as we saw, even importance on a truly grand trace needn't be especially temporally (or spatially) extended - think again of the example of the final spiritual leader. It is true, though, that one way to leave a robust lasting trace is by doing something truly important, and thereby

\footnotetext{
${ }^{35}$ See also my 'Importance, Value, and Causal Impact'. For a tentative defence of the view that temporal (as opposed to spatial) distribution may impersonally matter, see Temkin, L. (2015). 'Rationality with Respect to People, Places, and Times'. Canadian Journal of Philosophy, 45: 576-608.

${ }^{36}$ These are distinct variables given that one may, for example, be remembered for several centuries but most of one's fame may be located a century after one's death before dramatically tailing off. Another person may be overall just as known - in terms of, e.g., the number of people knowing them, the aggregate intensity of their engagement, etc., but that fame might be more evenly spread and concentrated over a shorter period.

${ }^{37}$ See again my 'Importance, Value, and Causal Impact'.

${ }^{38}$ For a discussion of the desire to leave a trace, and especially to be remembered, see Margalit, A. (2002). The Ethics of Memory. Harvard: Harvard University Press.
} 
becoming posthumously famous for a long time. But if there is further value to leaving a trace it seems to me to go beyond, and be independent of, the value associated with importance and (merited) fame. And it seems to me odd, even lopsided, to want to do something grandly important only, or even primarily, because that would leave a lasting trace.

Woody Allen famously quipped, 'I don't want to achieve immortality through my work; I want to achieve immortality through not dying. I don't want to live on in the hearts of my countrymen, I want to live on in my apartment'. ${ }^{39}$ Galen Strawson somewhere similarly writes that 'It's not being forgotten by others that matters, it's eternal future non-existence.' ${ }^{40}$

I think that both Allen and Strawson have in mind the idea of a leaving a trace. But it seems natural to extend this objection to a concern with posthumous importance and fame. However, as we saw, if importance and fame are at all valuable, then they won't stop having (or adding to) that value when one dies. Conversely, if one is simply rejecting that final value altogether, then the issue of death is irrelevant, since one should also reject it when the person in question is alive. Moreover, the personal value of importance and fame are simply distinct from the value to us of our continued life. Once we stop thinking of posthumous glory in terms of a kind of substitute afterlife, ${ }^{41}$ it makes no sense to complain that it cannot compensate for what we are deprived of by death, or that posthumous glory doesn't make our mortality any less definite and depressing. In fact, even if the personal value to you of importance can extend beyond your life it remains the case that death puts a severe limit on how much impact one can make on the world. Thus to recognize the value of importance and fame can make death even worse. But notice, conversely, that even if we had lived forever this wouldn't in itself address the existential concern to make a difference, and for that difference to be fittingly recognized. One could exist for eternity in insignificant obscurity. In fact, I have elsewhere argued that if God exists then His incomparable value and impact would make all of us humans insignificant on the grander scale, even if some of us will also enjoy eternal bliss. ${ }^{42}$ This is an implication that is recognized by many religious traditions, even if it is obscured by the common conflation of meaning and importance.

The things we that regularly describe as 'universal' are really preposterously parochial. Talk of literary immortality is similarly hyperbolic. Stendhal had a good run, better than he expected in his wildest dreams. But can we say with confidence that he'll be read much in two hundred years? And even in the unlikely event that, say, Shakespeare somehow remains a vital cultural influence until the last days of the solar system, this will still fall far short of anything approaching immortality.

The concern to be remembered by posterity is often ridiculed on this count. To quote Galen Strawson again: "what's the timescale of remembrance? In the end Ecclesiastes is right. In the end there is 'no remembrance of former things, nor will there be any remembrance of things that are to come amongst those who shall come after'."43

Let's suppose that Shakespeare would realize the personal good of glory to some ideal extent if his work was enjoyed and admired forever. It wouldn't remotely follow that it wouldn't be better, from his point of view, if Hamlet was admired for thousands of years rather than for several hundred, let alone for just a few decades, just as a life lasting two

${ }^{39}$ Allen, W. (1995). The Illustrated Woody Allen Reader. NY: Random House.

${ }^{40}$ Strawson, G. (2003). 'Blood and Memory'. The Guardian, 4 January.

${ }^{41}$ Unamuno famously described the urge to perpetuate one's name and fame as the 'shadow of immortality'—-see de Unamuno, M. (1921). The Tragic Sense of Life. London: Macmillan and Co.

${ }^{42}$ See Kahane, 'Our Cosmic Insignificance'. Conversely, we humans might be of immense cosmic importance - though not enjoy cosmic fame! - if God doesn't exist and we're alone in the universe, despite the fact that humanity will eventually go extinct, even if we go extinct in the not so distant future.

${ }^{43}$ Strawson, 'Blood and Memory'. 
hundred years is better than one lasting twenty, even if both pale in comparison with immortality. Though recall that it's not temporal extension per se that matters here but the size and quality of the audience, so to speak. It would make no difference, in terms of glory, whether Shakespeare's audience extended for a million year further on a sparsely populated Earth or for only a thousand more years in a more densely populated planet.

Moreover, there are two rather different ways of thinking of that audience. On the first, more is literally better: the ideal situation (focusing on fame) is getting appreciation from an indefinitely large potential audience. But an alternative view takes the potential audience as fixed. The best situation is getting as much appreciation from that audience (however big or small) as is fitting. On this second view, if Shakespeare or Einstein will be properly recognised till humanity's end, they will have realised this personal value to the maximal degree. I am not sure whether the latter view is correct with respect to fame, but I have argued elsewhere that something like this is true of importance - importance is always relative to the actual world, meaning that importance is always relative to the fixed amount of value that the world overall contains (or will end up containing) ${ }^{44}$ It is actually the idea of infinite value that makes it hard to see how anyone could make a difference to overall value and thus threatens the very idea of importance on the grandest scale. ${ }^{45}$

University of Oxford guy.kahane@philosophy.ox.ac.uk

${ }^{44}$ See again my 'Our Cosmic Insignificance' and 'Importance, Value, and Causal Impact'.

${ }^{45}$ This chapter was presented at the Meaning in Life and Knowledge of Death conference at the University of Liverpool. I'm grateful to the participants for very helpful comments. 